\title{
The Contribution of Islamic Micro Finance Towards Poverty Alleviation: A Case Study of Bank of Khyber Khud Kifalat Scheme
}

\author{
Muhammad Saleem Qazi \\ Visiting Lecturer, Pak Study Department \\ Bahauddin Zakriya University, Multan \\ Saleemtaunsvi82@gmail.com \\ Dr. Muhammad Adil \\ Assistant Professor, Management Sciences Department \\ Bacha Khan University, Charsadda \\ adil@bkuc.edu.pk \\ Dr. Saima Batool \\ Associate Professor, Department of Business Administration \\ Nur International University Lahore \\ Saima.batool@niu.edu.pk \\ Yasir Khan \\ Ph.D Scholar Qurtuba University Peshawar \\ yasirok62@yahoo.com
}

\begin{abstract}
The aim of this research is to investigate role of Microfinance in Poverty alleviation. Primary data was used in this research and was collected through personally administered questionnaires from 150 respondents. Results showed that most of the respondents were in favor of the Khud Kafalat scheme because it helped them in increasing their living standards and standard of education of their children due to establishing small scale businesses or expanding existing businesses. Moreover, Khud Kafalat Scheme has a very important role in Poverty alleviation and increased their gross monthly income. Furthermore, their satisfaction can also be depicted from the fact that although they observed no change in their employees' condition but on individual level, most of them, were still in favor of applying again for the loan, if needed, in the future.
\end{abstract}

Key words: Islamic Micro Finance, Poverty alleviation, Khyber Paktunkhwa

\section{Introduction}

Poverty is a vital hurdle to the present civilized world. In today's world, poverty is known to be the fundamental cause for disputes between countries. Poverty is the main problem which is badly impacting the world's developing nations. Pakistan is one of those nations which faces a similar problem. Pakistan reportedly has a poverty rate of 39 per cent (Abdullah, 2016). The governmental and nongovernmental organizations are working hard to overcome the country's rising poverty rate. Several 
forms of micro-finance schemes were implemented from time to time by the government for this reason.

Islam as a religion focuses much on alleviating poverty. The Holy Book, the Prophet's Ahadiths (PBUH) and the Actions of Prophet's Caliphs (PBUH) are found to be on the same page in providing adequate facilities to Muslim state people. The Quran unlawfully discourages the use of each other's belongings; instead, it lawfully allows the sharing of food and other gifts. For example, Those who believe do not illegitimately eat each other's belongings; you are allowed to do so only if you have a business relationship (Al Quran, al nisa, 29). Through different chapters, Quran also promotes the development of loans and financial assistance among themselves. And support one another in poverty, for example, and stop participating in poor practices (Al Quran, albaqara,58).The Prophet's ahadiths (PBUH) and his teachings also focus on helping the needy and the poor. The Prophet said like this that Allah repairs all of his deeds by one who is busy helping his Muslim brother. Moreover, Sydna Hazrat Abbas narrates this hadith that Allah does his seventy deeds (Al Bukahri, Babe Sadaqa) when someone is busy helping his Muslim brother for a valid task. There are hundreds of evidences in Islamic history in this regard. The Prophet's caliphs (PBUH) were also continuing along the same direction. A well-known caliph Hazrat umer saying is that "only I am responsible for the death of a dog on the bank of Farat (the name of a sea) because of hunger."

As a Muslim country, Pakistan has the central obligation of fighting poverty and providing its people with a stable climate. Several Microfinance banks have been launched for this purpose and offer diverse financial schemes. Waseela Microfinance Bank, Apna Microfinance Bank, Pak Oman Microfinance Bank, NRSP Microfinance Bank, Khushhali Bank, Tameer Microfinance Bank Limited are some of these banks. These banks have different schemes but the sole purpose is to get rid of the country's poverty. In addition to these full fledged Microfinance banks, traditional institutions also provide their customers with microfinance services.

Pakistan is one of the countries where there is extreme poverty. The government is committed to reducing the poverty rate and improving its citizen's living standards. Unfortunately there are few serious attempts to be made in this area. Numerous attempts have been made to fight poverty since the Microfinance Order passed by Pakistan State Bank in 2001, several schemes are being implemented in Pakistan, some of which are Akhuwat, Wasil Foundation, Wafaq Foundation, etc. All these are private schemes that work based on compassion and sympathy.Pakistan's government is also trying its best and as discussed above it has launched many banks and schemes. BOK's Khud Kafalt scheme is one of those schemes for poverty reduction initiated by the government. The present study is an attempt to explore the contributions of Islamic Microfinance Schemes to reducing the country's poverty. The focus of the study is on one of the Islamic Microfinance Schemes i.e., Khud Kafalat Scheme, launched by bank of Khyber (BOK), Pakistan.

\section{Problem statement}

People suffering from poverty need stable access to the same kind of financial services as others receive.One of the potential factors of deprivation, along with other factors, is the unavailability of low cost financial services. There is an urgent need to 
provide financial assistance to the poor and vulnerable to pull them out of the poverty line and allow them to live regular lives. Microfinance is one of those instruments that could provide vulnerable people with small scale loans. In the same regard Khud kafalat scheme of BOK is one of the initiatives took by provincial government in order to combat poverty. The present study is aimed to find out the extent to which Khud kafalat scheme of BOK has contributed in poverty alleviation.

\section{Objective of the Study}

- $\quad$ To find out role of Khud kafalat scheme of BOK in poverty alleviation.

\section{Hypotheses}

$\mathrm{H}_{1} \quad$ Khud Kafalt scheme of BOK has contributed significant role in poverty alleviation in Khyber pakhtunkhwa.

\section{Review of Literature}

The emergence of deprivation may be traced back to humanity's very life. Poverty was first raised by all of the relevant phenomenon's decision makers. And none other than Caliph Umar Bin Abdel Aziz's leaders succeed in removing poverty from its roots. It was evident in the era of Umer bin Abdel Aziz that the Islamic monetary system and its related principles were a good instrument for eradicating poverty; however, it can only be conceivable in a favorable environment to produce better results. That is the reason why the Muslim world is struggling to restore what Umar Bin Abdel Aziz did then in the current circumstances. In his age, Umer bin Abdul Aziz ensured that the well-off citizens of society had a proper system of zakat and Usher. The citizens of his age have found that there was no one to take Zakat or sadaqah in the entire Muslim Ummah. In addition to this Umer Bin Abdul Aziz has supported the development of Bait ul mall loans to farmers and businessmen (Abdelhak, 2011).

Poverty is recognized as one of the great human issues. To eradicate poverty remains at the top of the nations priorities. Microfinance was used to provide financial inclusion for the world's underdeveloped countries ' needy people (Banerjee, 2010). Microfinance is the most important tool used in this respect, allowing vulnerable people to access and stand on their own feet to the financial assistantship. There are numerous examples in literature of microfinance schemes from developed and underdeveloped countries. Pakistan and Bangladesh are among those Muslim countries that are suffering from the poverty problem and the majority of their population live below the poverty line. Both of these countries have launched many programs to reduce the disproportionate rate of poverty that have proved effective (Basit, 2012).

The concept of Islamic banking is emerging in Muslim and non-Muslim countries because it is in harmony with Sharia and aims to serve Muslim customers. Although most Islamic banks are in the Middle East and the developing countries, some global banks in developed countries have started to meet the demands of Islamic finance products.

Over past two decades, there have been a lot of improvements in the Islamic world, supporting Islamic funding and regeneration. The latest unprecedented incentive in the revenue of most Muslim Arab countries enters petrodollars in those countries, subsequently encouraging non-Muslim investors and financiers in the attacks of 9 / 
11. In the golf area now more vulnerability are captured. Finally, in order to attract these financial markets, a number of opportunistic states such as United Kingdom, United States and France are encouraging banks that provide Islamic banking services.Several specific studies have analyzed the progression of this specific area of finance. In actual, few studies have observed the risk of leading Islamic funding to the international financial system, giving them the amount of collected gasoline and the globalization environment. (Suderrajan and Ergio, 2002) discussed how financial institutions should take into consideration the specialty of those companies and their products in managing risks; This is the same period in 2008 for Chickham and Hesse. They analyzed potential channels that could affect global financial stability of Islamic finance. Finally, (Jobst, 2007) analyzed the legitimate and economic necessitate of the Shariah Agreement on the composition of Islamic security transactions.

Previous researches have evaluated the Islamic banking ability supported by the financial and management ratio, or use the parameters or parameters used for conventional banks. Absus-Samat, quoted in 1999, to the first study group; (Bashir, 1999) and (Hassan and Bashir, 2003). These documents focus on most countries in some countries or in the lowest number of countries in one country. In fact, the data of Islamic banks is not just such comparisons, but comparative studies in countries.

The Islamic banking is flourishing day by day in the Middle East and developing countries. In those countries, financial authorities have made reforms or allowed the entire Islamization of their financial system and allowed the Islamic banks to compete with the regular banks. Therefore, our concern is to measure the efficiency of Islamic and commercial banks, to assess their evolution and decision-making. Our study has been studied in 17 nations in the Middle East, Asia and Africa and UK. This objective of analysis allows us to analyze the potency of Islamic banks through differences in attributes in those countries. Compare with a model of commercial banks in the same country. We used a standard border approach (SFA) when we take into account a range of boundaries, to estimate the cost efficiencies of the period of 2001-2008 and to assess the cost estimation efficiency. Our results show that Islamic banks are more cost-efficient than conventional banks. Except for countries that have made reforms to better the environment for Islamic banks.

The two main determinants of financial and financial capital structure. Liquidity refers to managing liquid assets or a company's money to operate its daily activities or functions. Inflationary influence in the management of the financial institution and other economic sectors is very attractive. (Chamberlain \& Gordon, 2002) LIC of the company. This concept, adopted by Jose, (Lancaster and Stevens, 1996), argues that the Liquidation administration was the first to highlight institutions.

Since (Rehman A, 2013) liquidating means investing money into current liabilities and current liabilities within a year or less, it is of great importance to the company's activity. Payment argues that capital is very closely related to the functioning of the company and the cash needed to fund the company's daily income. Its effect on a company management is very interesting and attractive, and it is true that financial performance measurements are very difficult to achieve.

Lots of statements, arguments and opinions on the nature, character and significance of cash flow control. As a result, a company needs to expand its budget, which keeps 
the future risk at lower levels. Since the credit management fees, bad loans, losses and the possibilities of money should not be reduced, the price must be controlled.

Cash flow refers to the value and ability to meet a person's or its current or short-term debts. Or simply selling assets that can easily be sold anywhere in short-term and immediate sites. Short-term and long-term stable growth and inflation for success is vital. The cash flow helps to maximize its current value and the wealth of the company's shareholders. At the same time, the capital structure represents the debt and equity of the company. Each company owns its total assets, which operate in the best way of capital structure through loans and capital. The ability of the capital system to determine how to combine assets can be determined by the efficiency of the administration because the revenue on investment is governed by the capital structure. Sometimes it is referred to as "turning to investment." Investing in each company's capital, inventory, accounts receivables, and cash or marketed securities is a means of corporate growth. The best combination of capital structure components of the company helps the company's growth and profitability directly affect the company's profits and reduce the cost of capital to invest in profitable business channels. Providing loans and balances to raise financial health of companies. The company's capital structure is crucial to the survival and development of the company, which could affect instant profits.

Basically, the usual banking business is based on interest. Banks are simply obliged to pay money (installing customer deposits) and pay interest on given deposits. For making a profit, they pay and get high interest from debtors. On the way they are attracting new customers, they also offer their customers the largest and most essential banking services to their customers, including withdrawals, deposits, and cash purchase. While still questionable and debatable, some scholars have confirmed that the prohibition (in the words of Allah) is mentioned in the Qur'an. Therefore, in accordance with the Islamic rules, Islamic banks are banning other, money or interest. With the fast growing of the Islamic Bank in the previous 30 years, many Muslims have withdrawn from conventional or traditional banks and converted to Islamic banks. According to The Economist (2014), the total assets of Islamic financial institution has increased which are about \$ 2 trillion. Between 2009 and 2013, the annual rate of Islamic banking assets for Shariah-compliant claims increased to $17.6 \%$ and an increase of $19.7 \%$ by 2018 . These increased or growth rates are relatively new for the relatively new industry.

The principal source or inflow of capital for Islamic and traditional or conventional banks is the deposit / investment accounts. Deposit bank is considered a duty in the regular banks. The capital structure of a regular bank consists of equity and debt. This means increase in debt or the amount of debt that is higher than the bank's risk. In Islamic banks, however, deposit is not a responsibility or equality. It is now the capital system theory established in Islamic Banking (Altihani et al., 1999) and (Archer et al, 1998).

Banking sector is a major or main financial sector that affects economic growth. The development and growth of any economy depends largely on the stability of its banking sector means banks of the country are how much stable for investors and clients. It operates intermediate connecting surplus and defective units; Contributes to 
economic development by helping to fund the production purpose. Regular banking is based on interest. The Islamic bank implements Islamic Sharia as the basis of the process. In the GCC region, the Regular Bank and Islamic Bank offers its various products and services. Islamic banking services are of interest and are based on profit or loss and risk sharing and contribute and contribute Mudaaraba and Vakala (Agents) Agreement. In other words, the deposit approach was adopted rather than bank deposit based approach.

Islamic Banking collaborated with the Islamic Banking and Islamic Assessment System, co-ordinated by the Islamic Sharia policies with conventional well-being and risk management rules. Despite the differences and similarities between the traditional or usual bank and Islamic banks, both are in a competitive environment and should use the right risk management tool to prevent the dangers of the business. Number of studies have been carried out and researchers worked on regular banking and Islamic banking around the world including Awan, Hanif and Al Qasim. Most of the studies were centered on a comparison with the Islamic bank with the regular bank.

To ensure that the economy of any country is part of the economic and financial sector of the financial and banking sectors, so banking systems play an important or vital role in the world, and the government's economy stimulates monetary policy. However, all monetary or financial transactions are made by banks. Although these instruments are strict, they cannot trust their financial areas especially after the financial crisis or decline. Central banks and Governments try to stimulate the economy by utilizing monetary tools, but this is simply not a trick. After the global financial crisis, mortgage loans and unemployment rose significantly as many were homeless.

Like the usual bank, the Islamic bank is a middle man and wealthier among the rich. Following a typical bank interest-based policy, based on Islamic banking, free policy and profit loss (PLS), their businesses participate in the implementation of intermediaries (Mohamed and Manaravi, 2011). In theory, Islamic funding differs significantly from the regular fund. Specifically, Sharia does not allow for a compatible financial interest (riba), because products and services are not permitted to set the price and does not allow speculation and prohibits financing for certain activities. This creates clear differences in the financial and operational structures of Islamic and traditional banks. In practice, in practice, Islamic scholars create products like conventional banking products, and exchange rates with discounted payments and regulatory payments (Beck Ed, 2013).

Since the beginning of 1970, the Islamic bank has gained popularity and recorded significant growth in the years mentioned by Chevy and Saraf.The combined balance of Islamic banks increased from $\$ 150$ billion in 1990 to more than 300 shariacompliant firms operating in 80 countries, with about $\$ 1$ million in 2010 . The study focuses on a comparative project assessment between the regular banks in the Islamic Bank and the GCC region. We particularly discuss how banks and Islamic banks meet its different performance indicators.

On this basis, the relatively new theory is that the Islamic banks are getting the most conservative policies and aggressive investment policies they want to earn more than 
their usual things, since the bulk of their capital (deposit / investment accounts) are getting risk.

Therefore, the main hypothesis in this study is that Islamic banks do not have to increase their deposits to their share of additional risks because they have higher risks for investment. Hence, they are expected to invest in greater risk than the usual banks by accepting higher income and more aggressive investment policies of normal economic conditions. This hypothesis is cleared by the argument created by Archer and al. (1998) The shareholders of the Islamic Bank noted that "the amount of money that was deposited in the bank could not prevent a greater risk of their share by increasing their revenue from the macro bond." A similar argument was made by altihani and many others. (1999) "The concept of financial risk based on modern economic capital principles is not appropriate for Islamic banks".

Converting the short-term assets into liquidity will soon build up shareholders confidence. A company is called a mobilized company, which can quickly convert money into cash and with great speed. Usually the company uses various rates to calculate the Lecture, such as quick rates, current ratio, and soup quick rate and cash rates. This ratio is true about the company's fever. . While the two rates are similar, the quick rate provides the most accurate solution to the effectiveness of the business to pay its current debts. The quick rate avoids the most liquid of current assets. The most famous error in stock is not to convert it into cash. The quickest rate is the practical identification of the short-term liquidity of the business. The quick rate shows a company's ability to meet short-term loans with the company's most liquid resources. Maximum quick rate of production shows improved conditions.

The banking firms plays an important role in the development of international and national economic growth, with the Bank's performance assessment highly researchers and trainers (Darrene, 2006). In that structure, many studies focused on the performance of the banks and the banks in particular for European and American countries. However, there has been a limited study to analyze Arab banking operations such as the Arabian Bank during the role and significance of this region in economic development. These studies have only made a comparative analysis between the usual and Islamic banks, compare bank performance (Jogens, Isseldin, \& Papas, 2012); (Onaki \& Onaki, 2013). Therefore, lack of literature in performance determinants is required to examine the factors affecting the efficiency of the banks and to link the factors to performance measurement. Banking performance assessment is important for many parties, such as depositors, bank managers, investors. It helps investors to make decisions for investment or is not in banks because bank managers can help the bank managers to make the best decision to improve bank conditions for bank executives. Depositors can offer some guidance to select the best service offered by the banks. From this point of view, the current objective is to examine differences in banking performance between Islamic banks.

Conventional banks providing micro finances entails several issues. Microfinance for example is a small scale. It is true that small businesses sometimes become big business. Yet, they don't do it more often. It is unusual to build anything bigger which fully supports the family and creates jobs. Costly, microcredit loans are the most important downside among all. Small companies may not be able to bear the high 
costs of microcredit schemes that are inflating. Research indicates that these interestbased loans have raised the problems of poor people and failed to achieve the goals of poverty reduction. Second, the existence of interest is the main cause of this form of scheme's failure itself. Islam forbids focus on several verses with the word "Riba." Islamic banks also launched the alternative goods of their traditional counterpart for this reason. Islamic microfinance schemes are among those alternatives that are said to be interest-free.The other problem is that one might not et as much funding as he needs. One might find that he need extra funding to really get a business off the ground(Khan,Ali, Batool,\& Ali 2017).

Kazim (2010) argued that small-scale credit allows individuals to pick reserve funds, security, and diversification of micro. This allows the general population to organize work alongside small-scale enterprise for them. The administrations given by micro credit will add to the financial development stream, and in the short as well as long term optimum capacity can be reached along these lines.

\section{Research Methodology}

The Section discussed the study design population, sample size, method and data collecting techniques.

\section{Population and Sample Size}

A sample of 150 clients who have taken services from the Khud Kafalat Scheme is derived by applying convenient sampling technique. These clients are contacted personally and a well structured questionnaire is filled from them. The time period for the study comprises from 2014 to 2016 . The limited time span for the study is due to the fact that Khud Kafalt scheme of BOK has been launched in 2014.

\section{Data Source and Data Collection}

As mentioned earlier, 150 clients of Khud Kafalat Scheme of BOK are contacted for responses. Firstly questionnaire is distributed to the targeted respondents and are filled from them. Based on responses provided, further analysis are performed.

\section{Research Instrument}

The data is analyzed through SPSS. The researcher has presented responses of respondents in the form of Graphs, frequency distributions, percentages and other statistical measures. For this purpose data is presented in tabulated form.

\section{Quantitative measures of Statistical terms}

- $\quad$ Arithmetic mean It refers to the mean value or simply the average value of a set of data. It can be calculated by the following formula

A.M $=$ Sum of all observations

No of Observations

- $\quad$ Standard Deviations It refers to the deviation of data from its mean value. It shows the spread in data. Standard deviation is the square root of variance.

It can be given by the formula 


$$
\mathrm{s}=\sqrt{\frac{\sum(x-\bar{x})^{2}}{n-1}}
$$

\section{Results And Discussions}

This chapter comprises of the analysis and findings. Findings are presented in form of tables and graphs (both frequency graphs and count graphs). Different techniques have been applied in order to explain data. Moreover, values like $112(74.7 \%)$ on the top of each bar in the count graphs represent number i.e. 112 and percentage of the number i.e. $74.7 \%$ respectively.

\begin{tabular}{|c|c|c|c|c|c|}
\hline \multicolumn{6}{|c|}{ Table 4.1 Descriptive Statistics } \\
\hline \multicolumn{6}{|c|}{ Descriptive Statistics } \\
\hline & $\mathrm{N}$ & $\underset{\mathrm{m}}{\operatorname{Minimu}}$ & $\begin{array}{l}\text { Maximu } \\
\mathrm{m}\end{array}$ & Mean & $\begin{array}{l}\text { Std. } \\
\text { Deviati } \\
\text { on }\end{array}$ \\
\hline What is your gender? & 150 & .00 & 1.00 & .2533 & .43638 \\
\hline Age of the respondent & 150 & 1.00 & 3.00 & $\begin{array}{r}1.806 \\
7\end{array}$ & .67254 \\
\hline $\begin{array}{l}\text { Gross monthly Income of the respondent } \\
\text { in PKR }\end{array}$ & 150 & 1.00 & 3.00 & $\begin{array}{r}1.953 \\
3\end{array}$ & .83011 \\
\hline Purpose of getting loan of the respondent & 150 & 1.00 & 4.00 & $\begin{array}{r}1.826 \\
7\end{array}$ & .89553 \\
\hline Did the purpose of getting loan fullfilled? & 150 & 8.00 & 1.00 & .2333 & .42437 \\
\hline $\begin{array}{l}\text { Do you think the amount you recieved in } \\
\text { terms of Khud Kafalat Scheme was } \\
\text { sufficient to start a new Business? }\end{array}$ & 150 & .00 & 1.00 & .2667 & .44370 \\
\hline $\begin{array}{l}\text { In which sector did you invest the money } \\
\text { recieved by Khud Kafalat Scheme? }\end{array}$ & 150 & 1.00 & 5.00 & $\begin{array}{r}3.240 \\
0\end{array}$ & 1.40316 \\
\hline $\begin{array}{l}\text { Did this loan helped you in getting your } \\
\text { children education better? }\end{array}$ & 150 & .00 & 1.00 & .2800 & .45050 \\
\hline $\begin{array}{l}\text { Did the Scheme contribute in increasing } \\
\text { your life standards? }\end{array}$ & 150 & .00 & 1.00 & 2333 & .42437 \\
\hline $\begin{array}{l}\text { Did the Scheme contribute in increasing } \\
\text { your gross monthly income? }\end{array}$ & 150 & .00 & 1.00 & .2533 & .43638 \\
\hline $\begin{array}{l}\text { In your opinion, Is the Scheme } \\
\text { contributing in Poverty Alleviation? }\end{array}$ & 150 & .00 & 1.00 & .2200 & .41563 \\
\hline $\begin{array}{l}\text { Are you satisfied with the Khud Kafalat } \\
\text { Scheme? }\end{array}$ & 150 & .00 & 1.00 & .2200 & .41563 \\
\hline Did you pay the installments easily? & 150 & .00 & 1.00 & .2467 & .43252 \\
\hline How many people have you employed? & 150 & 1.00 & 4.00 & 1.226 & .50695 \\
\hline
\end{tabular}




\begin{tabular}{|l|c|r|r|r|r|}
\hline & & & & 7 & \\
\hline $\begin{array}{l}\text { Did you observe any change in living } \\
\text { standards of your employees? }\end{array}$ & 150 & .00 & 1.00 & .7733 & .42008 \\
\hline $\begin{array}{l}\text { Did you motivate other people of your } \\
\text { community? }\end{array}$ & 150 & .00 & 1.00 & .2200 & .41563 \\
\hline $\begin{array}{l}\text { In future, if you need loan, will you apply } \\
\text { again for Khud Kafalat Scheme? }\end{array}$ & 150 & .00 & 1.00 & .2267 & .42008 \\
\hline Valid N (listwise) & 150 & & & & \\
\hline
\end{tabular}

\section{Descriptive Statistics}

The above table shows descriptive statistics for the data used. The table shows that total number of observations in each case is $150(\mathrm{~N}=150)$. Furthermore, it also shows the minimum and maximum values along with their mean values and standard deviation from their mean values.. Standard deviations for all the cases can be seen in the last column.

Gross Monthly Income of the respondents in PKR

\begin{tabular}{|l|l|r|r|r|r|}
\hline \multicolumn{7}{|c|}{ Gross monthly Income of the respondent in PKR } \\
\hline \multirow{2}{|c|}{} & $\begin{array}{c}\text { Frequenc } \\
\text { y }\end{array}$ & Percent & $\begin{array}{c}\text { Valid } \\
\text { Percent }\end{array}$ & $\begin{array}{c}\text { Cumulative } \\
\text { Percent }\end{array}$ \\
\hline \multirow{3}{*}{ Valid } & Less than 12000 & 55 & 36.7 & 36.7 & 36.7 \\
\cline { 2 - 6 } & 13000 to 20000 & 47 & 31.3 & 31.3 & 68.0 \\
\cline { 2 - 6 } & 21000 to 30000 & 48 & 32.0 & 32.0 & 100.0 \\
\cline { 2 - 6 } & Total & 150 & 100.0 & 100.0 & \\
\hline
\end{tabular}

\section{Purpose of getting loan:}

Results for the purpose of getting loan are shown in the following table and graphs. It can clearly be seen from the results that out of the total 150 respondents, 68 i.e. $45.3 \%$ took loan for the sake of expanding the business, 61 i.e. $40.7 \%$ took loan to start a new business, 14 i.e. $9.3 \%$ took it for doing some other business while only 7 i.e. $4.7 \%$ respondents took it for the sake of their kids' education. This clearly shows that most of the respondents got the loan for either expanding the existing businesses or starting new ones.

Table 4.5 Purpose of getting loan of the respondent

\begin{tabular}{|l|l|r|r|r|r|}
\hline \multicolumn{6}{|c|}{ Purpose of getting loan of the respondent } \\
\hline \multicolumn{2}{|c|}{} & $\begin{array}{c}\text { Frequen } \\
\text { cy }\end{array}$ & $\begin{array}{c}\text { Perce } \\
\text { nt }\end{array}$ & $\begin{array}{c}\text { Valid } \\
\text { Percent }\end{array}$ & $\begin{array}{l}\text { Cumulative } \\
\text { Percent }\end{array}$ \\
\hline \multirow{2}{*}{$\begin{array}{l}\text { Vali } \\
\text { d }\end{array}$} & $\begin{array}{l}\text { Starting } \\
\text { Business }\end{array}$ & 61 & 40.7 & 40.7 & 40.7 \\
\cline { 2 - 6 } & $\begin{array}{l}\text { Expanding } \\
\text { Business }\end{array}$ & 68 & 45.3 & 45.3 & 86.0 \\
\cline { 2 - 6 } & Kids Education & 7 & 4.7 & 4.7 & 90.7 \\
\cline { 2 - 6 } & Others & 14 & 9.3 & 9.3 & 100.0 \\
\cline { 2 - 6 } & Total & 150 & 100.0 & 100.0 & \\
\hline
\end{tabular}




\section{CONCLUSION}

Aim of this study is to find out the role of Khud Kafalat Scheme of BOK in poverty alleviation particularly in Peshawar, Khyberpakhyunkhwa.Khud Kafalt programme of $\mathrm{BOK}$ is one of those initiatives introduced by the government to reduce poverty. The present thesis is an attempt to examine the contributions of Islamic Microfinance Schemes to the deprivation of the country's development. The focus of the study is on one of the Islamic Microfinance Schemes i.e., Khud Kafalat Scheme, launched by bank of Khyber (BOK), Pakistan. For this purpose a sample of 150 respondents has been chosen and contacted to fill questionnaire. Responses have been analyzed with the help of descriptive study. From the findings, it can be inferred that the respondents were optimistic and in favor of the program, as most respondents said, the purpose of borrowing was fulfilled, as well as improving their living standards and their children's education levels. In fact, it also helped to increase respondents ' gross monthly income, and thus to alleviate poverty, and most respondents were pleased with the program. Furthermore, based on the above analysis, it can also be inferred that installments were also easy to pay and that the majority of respondents also suggested about the scheme to other people in community.

\section{Recommendations}

- $\quad$ People should be encouraged to apply for loan of Khud Kafalat scheme.

- Government should take keen interest in making the scope of scheme broader.

- The loan amount should be increased so that people can easily start the business of their own desire.

- $\quad$ Loan processing time should be minimum.

\section{References}

Abdelhak, (2011). How poverty can be controlled? A case of South Asian countries. Journal of Management and Accounting, 43(2), 45-58.

Akram, M., \& Hussain, I. (2011). The Role of Microfinance in uplifting Income Level: A study of District Okara - Pakistan. Interdisciplinary Journal of Contemporary Research in Business, Vol. 2, No. 11.

Awojobi, O., \& Bein, M. A. (2011). Microfinancing for Poverty Reduction and Economic

Basit, A. (2010). Microfinance institutions in Bangladesh: achievements and challenges. Journal of Managerial Finance, Vol. 35 No. 12, 999-1010.

Bucciferro, J. (2007), Micro-Finance Impact in Chile: A Tale of two Cooperatives (http://www.spot.colorado.edu)

Development; a Case for Nigeria. International Research Journal of Finance and Economics (72), 159-168.

Dusuki, A. W. (2008). Banking for the poor: the role of islamic banking in microfinance initiatives. 24 (1), 49-66.

Fehmeen (2010). Microfinance Banks and Poverty Alleviation in Nigeria. Journal ofSustainable Development in Africa, 12, No.6,, 177-191.

Hossain, M. K. (2012). Measuring the Impact of BRAC Microfinance Operations: A Case Study of a village. International Business Research, Vol. 5, No. 4. 
Iqbal, M. (2008). Impact of Microfinance on Poverty alleviation in Bangladesh. International journal of Management and Finance, 52(1), 2-17.

Karim, A. (2013). The explanatory and predictive scope of Microfinance in Poverty reduction. Journal of social sciences, 4(3), 359-373.

Kazim (2010). Rcovery of micro credit in Pakistan: Implications for enterprise development and Poverty alleviation. Management Research Review, 34 (2), 236-247 Khan, M. (2008). An Application of Islamic banking Principles to Microfinance, Technical A study of United Nations Development Programme and World Bank.

Mahmood, S. (2011). Microfinance and women entrepreneurs in Pakistan. International Journal ofGender and Entrepreneurship , 3 (3), 265-274.

S.M.Banerjee, (2010). Poverty in the $3^{\text {rd }}$ word and its solution. Journal of Managerial Finance, 63(1), 1-18.

Shirazi, N. S., \& Khan, A.U. (2009). Role of Pakistan Poverty Alleviation Fund's Micro Credit in Poverty Alleviation. A Case of Pakistan. Pakistan Economic and Social Review Volume 47, No. 2, 215-228.

Khan, Y., Ali, L., Batool, S., \& Ali, A. (2017). Growth \& Profitability of Private Commercial Banks: Major Indicator of Its Dividend Policy. American Journal of Operations Management and Information Systems, 2(4), 92. 